\title{
Microenvironment and photosynthesis of zooxanthellae in scleractinian corals studied with microsensors for $\mathrm{O}_{2}, \mathrm{pH}$ and light
}

\author{
Michael Kühl $^{1}$, Yehuda Cohen ${ }^{2}$, Tage Dalsgaard ${ }^{3}$, Bo Barker Jørgensen ${ }^{1}$, \\ Niels Peter Revsbech ${ }^{4}$
}

\author{
${ }^{1}$ Max Planck Institute for Marine Microbiology, Fahrenheitstr. 1, D-28359 Bremen, Germany \\ ${ }^{2}$ Division of Microbial and Molecular Ecology, Life Science Institute, Hebrew University of Jerusalem, \\ Jerusalem 91904, Israel \\ ${ }^{3}$ National Environmental Research Institute, Department of Freshwater Ecology, PO Box 314, Vejlsøvej 25, \\ DK-8600 Silkeborg, Denmark
}

${ }^{4}$ Department of Microbial Ecology, Institute of Biological Sciences, University of Aarhus, Ny Munkegade Build. 540, DK-8000 Aarhus C, Denmark

\begin{abstract}
During experimental light-dark cycles, $\mathrm{O}_{2}$ in the tissue of the colonial scleractinian corals Favia sp. and Acropora sp. reached $>250 \%$ of air saturation after a few minutes in light. Immediately after darkening, $\mathrm{O}_{2}$ was depleted rapidly, and within 5 min the $\mathrm{O}_{2}$ concentration at the tissue surface reached $<2 \%$ of air saturation. The $\mathrm{pH}$ of the tissue changed within $10 \mathrm{~min}$ from about 8.5 in the light to 7.3 in the dark. Oxygen and $\mathrm{pH}$ profiles revealed a diffusive boundary layer of flow-dependent thickness, which limited coral respiration in the dark. The light field at the tissue surface (measured as scalar irradiance, $E_{0}$ ) differed strongly with respect to light intensity and spectral composition from the incident collimated light (measured as downwelling irradiance, $E_{\mathrm{d}}$ ). Scalar irradiance reached up to $180 \%$ of $E_{\mathrm{d}}$ at the coral tissue surface for wavelengths subject to less absorption by the coral tissue (600 to $650 \mathrm{~nm}$ and $>680 \mathrm{~nm})$. The scalar irradiance spectra exhibited bands of chlorophyll a (chl a) $(675 \mathrm{~nm})$, chl $c(630$ to $640 \mathrm{~nm})$ and peridinin $(540 \mathrm{~nm})$ absorption and a broad absorption band due to chlorophylls and carotenoids between 400 and $550 \mathrm{~nm}$. The shape of both action spectra and photosynthesis vs irradiance ( $P$ vs $I$ ) curves depended on the choice of the light intensity parameter. Calculations of initial slopes and onset of light saturation, $I_{k}$, showed that $P$ vs $E_{0}$ curves exhibit a lower initial slope and a higher $I_{k}$ than corresponding $P$ vs $E_{\mathrm{d}}$ curves. Coral respiration in light was calculated as the difference between the measured gross and net photosynthesis, and was found to be $>6$ times higher at a saturating irradiance of $350 \mu$ Ein $\mathrm{m}^{-2} \mathrm{~s}^{-1}$ than the dark respiration measured under identical hydrodynamic conditions (flow rate of 5 to $6 \mathrm{~cm} \mathrm{~s}^{-1}$ ).
\end{abstract}

KEY WORDS: Light-enhanced respiration $\cdot \mathrm{O}_{2}$ and $\mathrm{pH}$ dynamics - Action spectra - $P$ vs $I$ curves . Scalar irradiance

\section{INTRODUCTION}

Symbiotic photosynthetic dinoflagellates (= zooxanthellae) are common inhabitants of many metazoan animals in the tropics, e.g. foraminifera, porifera and cnidarians (Trench 1981). In the polyp tissue of reef corals, high densities of zooxanthellae belonging to the genus Symbiodinium are found (Porter et al. 1984). These are among the most important primary produc- ers in tropical reef communities, estimated to account for 1 to $10 \%$ of total benthic production on a global scale (Muscatine 1990).

Studies of the photophysiology of zooxanthellae and their interaction with the host coral have inherent methodological problems due to the close interaction of zooxanthellae and coral metabolism within the $<0.5$ to $1 \mathrm{~mm}$ thin layer of tissue growing on the calcified coral skeleton. Carbon fixed by the zooxanthellae 
might be used for biosynthesis and respiration within the symbionts or translocated to the surrounding animal tissue, where it is used for respiration and biosynthesis (Muscatine et al. 1981, Falkowski et al. 1984). Part of the fixed C is excreted e.g. as mucus, or is incorporated into skeletal carbonate. Oxygen produced by zooxanthellae photosynthesis is used partly for symbiont respiration and partly for coral respiration. This intimate association between autotrophic and heterotrophic processes in corals (and in many other algal-animal symbioses) makes the quantitative and spatial separation of respiration and photosynthesis difficult when ${ }^{14} \mathrm{C}$ isotopes or $\mathrm{O}_{2}$ exchange methods are used (Muscatine et al. 1981, Muscatine 1990). Similar methodological problems exist in measurements of the primary production in sediments inhabited by microalgae and in photosynthetic microbial mats (Revsbech et al. 1981). A method for measuring gross photosynthesis independent of respiration is available based on the use of $\mathrm{O}_{2}$ microelectrodes (Revsbech et al. 1981, Revsbech \& Jørgensen 1983).

The microenvironment of the zooxanthellae is virtually unstudied, although microsensors for $\mathrm{pH}$ and $\mathrm{O}_{2}$, and the light-dark shift technique for photosynthesis measurements, have previously proven useful in the study of chemical gradients and transport mechanisms within algal-animal symbiosis (Jørgensen et al. 1985, Revsbech \& Jørgensen 1986). The few published $\mathrm{O}_{2}$ microelectrode measurements in corals have dealt with the diffusive boundary layer (DBL), which regulates the diffusive exchange between the coral tissue and the surrounding seawater (Patterson 1992, Shashar et al. 1993). The dynamics of $\mathrm{pH}$ and $\mathrm{O}_{2}$ in layers of endolithic algae in the coral skeleton has also been studied with $\mathrm{O}_{2}$ microelectrodes and $\mathrm{pH}$ minielectrodes (Shashar \& Stambler 1992).

Together with the chemical microenvironment, the light field inside the coral tissue is the most important factor regulating zooxanthellae photosynthesis. The optical properties of coral tissue are not known and only a few studies of the light field near coral reefs have been published [Roos 1967 (cf. Falkowski et al. 1990), Jaubert \& Vasseur 1974, Brakel 1979, Williams \& Carpenter 1990]. Recently, fiber-optic microprobes have been developed to measure directional radiant fluxes (field radiance) and spherically integrated total radiant flux (scalar irradiance) (Jørgensen \& Des Marais 1986, Kühl \& Jørgensen 1992, Lassen et al. 1992). Microscale light measurements with these probes in sediments and microbial mats demonstrated that the light field near the sediment surface may be very different in spectral composition and intensity from the incident radiant flux (irradiance) (Kühl \& Jørgensen 1992, 1994, Lassen et al. 1992, Kühl et al. $1994 \mathrm{a}, \mathrm{b})$. The scalar irradiance in sediments reached up to $200 \%$ of incident irradiance at the sediment surface due to intense multiple scattering. The combination of the incident collimated light with diffuse scattered light, which was spectrally altered due to absorption by photopigments in the sediments, resulted in a strong spectral distortion relative to the incident light. Similar effects of light scattering have been postulated to occur in corals (Brakel 1979, Falkowski et al. 1990) but to our knowledge no measurements of the light field at the level of single corals are available.

In this study we present direct measurements of $\mathrm{O}_{2}$, $\mathrm{pH}$, light and photosynthesis in the tissue of scleractinian corals. The goal was to characterize the chemical and physical microenvironment of the zooxanthellae and their surrounding coral host. Our results represent point measurements within single coral polyps and demonstrate basic principles of respiration and photosynthesis regulation in corals.

\section{MATERIALS AND METHODS}

Sampling and experimental setup. Small branches of Acropora sp. and Favia sp. were sampled by SCUBA diving from 5 to $10 \mathrm{~m}$ depth in the Gulf of Aqaba next to the H. Steinitz Marine Biological Laboratory, Eilat, Israel. The in situ seawater temperature was 20 to $23^{\circ} \mathrm{C}$ and maximal light intensities at the sampling depth reached $980 \mu$ Ein $\mathrm{m}^{-2} \mathrm{~s}^{-1}$ downwelling irradiance (Shashar et al. 1993). Most specimens had been exposed to natural light conditions and exhibited pale yellow-brownish/green tissue. One colony head of Favia sp. had been exposed for an extended period ( $>2$ yr; Razi Wigo pers. comm.) to very low light conditions in the shade of a larger coral assemblage and had dark chocolate-brown tissue.

After sampling, the corals were transferred directly to an aquarium with continuously aerated seawater kept at room temperature $\left(21\right.$ to $\left.23^{\circ} \mathrm{C}\right)$. Water movement in the aquarium was created by blowing air from an aquarium pump onto the water surface through a Pasteur pipette. The approximate flow velocity of the water over the coral was determined by timing the movement of small suspended particles in the water under a dissection microscope. Visible light was incident vertically from above using a tungsten-halogen lamp of constant color temperature but variable light intensity (Schott KL1500 with neutral density filters) and a daylight filter inserted in the light path. The lamp was equipped with a fiber-optic cable with a collimating lens. Experiments were done within 24 to $42 \mathrm{~h}$ after sampling.

Oxygen and $\mathrm{pH}$ measurements. Oxygen concentration was measured with Clark-type $\mathrm{O}_{2}$ microelectrodes (Revsbech \& Ward 1983) connected to a custom-built 
picoammeter. In the Favia sp. measurements the $\mathrm{O}_{2}$ microelectrodes were also equipped with a guard cathode (Revsbech 1989). Signals were either recorded on a strip-chart recorder or collected by a computer via an A/D card and a custom-made Pascal program. The electrodes had a tip diameter of 6 to $12 \mu \mathrm{m}$, a $90 \%$ response time of $<0.5 \mathrm{~s}$, and a stirring sensitivity of 1 to $2 \%$. Linear calibration of the $\mathrm{O}_{2}$ microelectrodes was done from readings of the electrode current in air-saturated seawater and in nitrogen-flushed seawater. The $\mathrm{O}_{2}$ concentration in air-saturated seawater was calculated from measurements of salinity and temperature using the formula given by Garcia \& Gordon (1992).

$\mathrm{pH}$ was measured with glass microelectrodes (Revsbech \& Jørgensen 1986) connected to a high impedance electrometer (Radiometer $\mathrm{pH}$ meter or Keithley type 617) with a calomel electrode (Radiometer type 401) as a reference. The tip diameter of the $\mathrm{pH}$ microelectrodes was 30 to $50 \mu \mathrm{m}$. Signals were recorded on a strip-chart recorder. Electrodes were calibrated at room temperature in standard $\mathrm{pH}$ buffers $\mathrm{pH} \mathrm{4,7,8}$ and 9) and exhibited a near-Nernstian response of 58 to $60 \mathrm{mV}$ per $\mathrm{pH}$ unit.

Light measurements. Incident downwelling quantum irradiance was measured with an underwater 400 to $700 \mathrm{~nm}$ quantum irradiance meter (LiCor) or with an underwater 400 to $700 \mathrm{~nm}$ scalar irradiance meter (1.5 cm probe diameter; Biospherical Instruments) positioned over a light well of black PVC at approximately the same distance and position in the collimated light field as the coral sample. Microscale light measurements were done in Favia sp. corals with a fiber-optic scalar irradiance microprobe (Lassen et al. 1992, Kühl et al. 1994b) connected to a custom-built light meter consisting of a photomultiplier (Hamamatzu HC120-05) equipped with a hot mirror (Melles Griot) transmitting only visible light to the detector. By covering the coral tissue with a small piece of black velvet, measurements of downwelling light intensity were done with the fiber-optic scalar irradiance sensor positioned at approximately the same distance from the light source as the coral tissue surface. The measurements of scalar irradiance presented in this study were all normalised to this measure of downwelling irradiance. A direct conversion of microscale light measurements into absolute units of light intensity was not possible as the fiber-optic light meter was not spectrally calibrated.

Besides measurements of visible light integrated from 400 to $700 \mathrm{~nm}$, we also measured spectral scalar irradiance. This was done by the same procedure as described above but with a continuous 400 to $720 \mathrm{~nm}$ interference filter (HBW 10 to $14 \mathrm{~nm}$, Schott) mounted in a holder at the output of the fiber-optic lamp (more details in Jørgensen \& Des Marais 1986). By sliding the interference filter in the holder it was possible to scan through the visible spectrum in $10 \mathrm{~nm}$ steps illuminating the coral with monochromatic light.

Positioning of microsensors. All microsensors were positioned by either a manually operated or a motorized micromanipulator (Märtzhäuser Germany; L.O.T. Germany) controlled by a computer and custom-made Pascal software. In the Acropora sp. samples, measurements were done with the microelectrodes mounted vertically and the light incident at an angle. In most of the Favia sp. experiments, the direction of measurement was at $45^{\circ}$ relative to the vertically incident light. Measurements were done in vertical steps of 50 to $100 \mu \mathrm{m}$. Determination of the tissue surface position was done by observation of the microsensors under a dissection microscope while slowly approaching the surface. In the following, all depths are related to the tissue surface (depth $=0$ ), where negative and positive depths indicate depth above and below the tissue surface, respectively.

Gross photosynthesis measurements. Gross photosynthetic rates $\left(\mathrm{nmol} \mathrm{O}_{2} \mathrm{~cm}^{-3} \mathrm{~s}^{-1}\right)$ in the tissue were determined with $\mathrm{O}_{2}$ microelectrodes by the light-dark shift method (Revsbech \& Jørgensen 1983). By this method the gross rate of photosynthesis is estimated as the rate of $\mathrm{O}_{2}$ depletion during $<1$ to $2 \mathrm{~s}$ after the onset of darkness, assuming (1) a steady-state $\mathrm{O}_{2}$ profile before darkening, (2) an identical $\mathrm{O}_{2}$ consumption before and initially during the dark period, and (3) identical diffusive fluxes during the measurements [a detailed discussion of the light-dark shift method can be found in Revsbech \& Jørgensen (1983) and Glud et al. (1992)]. The gross photosynthetic rates determined by use of $\mathrm{O}_{2}$ microelectrodes may include carbon equivalents that are subsequently lost through photorespiration (Glud et al. 1992).

Net photosynthesis and respiration. Diffusive fluxes of $\mathrm{O}_{2}, J(x)$, were calculated from steady-state $\mathrm{O}_{2}$ profiles by Fick's first law of diffusion (Revsbech \& Jørgensen 1986):

$$
J(x)=-\Phi D_{\mathrm{s}} \frac{\partial C(x)}{\partial x}
$$

where $\partial C / \partial x$ is the slope of the $\mathrm{O}_{2}$ profile at depth $x, \Phi$ is the porosity, and $D_{\mathrm{s}}$ is the apparent diffusion coefficient of $\mathrm{O}_{2}$. In seawater $\Phi D_{\mathrm{s}}=D_{0}$, the molecular diffusion coefficient of $\mathrm{O}_{2}$ in water, which is a function of temperature and salinity (Broecker \& Peng 1974, Li \& Gregory 1974, N. B. Ramsing \& J. Gundersen unpubl. data). In our case $D_{0}=2.02 \times 10^{-5} \mathrm{~cm}^{2} \mathrm{~s}^{-1}$ [calculated from a seawater temperature of $21^{\circ} \mathrm{C}$ and a salinity of $40 \%$ by the formula in Li \& Gregory (1974)].

The total flux of $\mathrm{O}_{2}$ out of the photosynthetic part of the coral tissue, i.e. the sum of the downward flux into 
the coral skeleton and the flux of $\mathrm{O}_{2}$ into the overlying water, is a measure of the net photosynthesis in the photic zone (Jensen \& Revsbech 1989). The $\mathrm{O}_{2}$ profiles measured in Favia sp. tissue showed a much smaller flux of $\mathrm{O}_{2}$ from the tissue into the coral skeleton than into the overlying water (i.e. the slopes of the $\mathrm{O}_{2}$ gradients were almost zero close to the skeleton). This is due to the low permeability of the coral skeleton to dissolved $\mathrm{O}_{2}$, which is several orders of magnitude lower than in water and tissue (Constanz 1986, Patterson 1992), and which acted as a diffusion barrier. Net photosynthesis was thus calculated as the flux of $\mathrm{O}_{2}$ into the overlying water. Total respiration in the light was calculated by subtracting net photosynthesis from the depth-integrated rate of gross photosynthesis (Jensen \& Revsbech 1989). Total respiration in the dark was calculated as the diffusional flux of $\mathrm{O}_{2}$ into the coral tissue based on the $\mathrm{O}_{2}$ gradient in the DBL above the tissue (Jørgensen \& Revsbech 1985).

Action spectra. Photosynthesis as a function of the spectral composition of incident light was measured in Acropora sp. using monochromatic light (10 to $14 \mathrm{~nm}$ half band width) with the interference filter setup described above. Light saturation curves were determined for 5 different wavelengths spanning the visible spectrum. The incident light intensity was then chosen to ensure that photosynthesis was not saturated at any wavelength in the visible spectrum. The actual incident irradiance was measured for each wavelength with a spectrally calibrated quantum irradiance sensor (LiCor). The measured photosynthetic rates were normalized to a (nonsaturating) light intensity of $100 \mu$ Ein $\mathrm{m}^{-2} \mathrm{~s}^{-1}$ (more details in Jørgensen et al. 1985).

Experimental difficulties. Coral polyps are able to contract or expand their tissue in response to environmental stimuli, e.g. physical disturbance by a microsensor, changes in light intensity or air exposure (Brown et al. 1994). This response created difficulties for our microsensor measurements in the coral tissue. Significant tissue movements resulted in noisy microsensor signals due to the physical impact on the thin sensor tip. Tissue around the polyp mouth was particularly subject to frequent contractions and expansions, and we avoided doing measurements in this region. Tissue moved much less in the region on and in between the ridges of calcified coral skeleton surrounding the mouth opening, and most measurements were done in this part of the corals, where the tissue thickness varied from $<0.5 \mathrm{~mm}$ to $\sim 1 \mathrm{~mm}$ (see also Fig. 7). During all measurements the measuring spot was observed frequently via a dissection microscope in order to avoid artefacts due to tissue movements.

An additional problem was the copious secretion of mucus by the corals, especially in Favia sp. A thin layer of mucus was frequently observed covering the coral tissue. Only in a few measurements did we succeed in penetrating the tissue directly with the microelectrode without inducing enhanced mucus secretion, while in most cases the tissue was only compressed by the microsensors. We tried to cut the tissue with a small hypodermic needle or with the tip of a scalpel before inserting the microsensors into the tissue. This resulted in the secretion of large amounts of mucus, which coated the tip of the microsensors and significantly affected their response. In most cases our measurements were thus limited to the upper 0.0 to $0.2 \mathrm{~mm}$ of the tissue and the overlying water. However, this still allows reliable measurements of $P$ vs $I$ curves and of action spectra of the zooxanthellae photosynthesis.

\section{RESULTS}

\section{Oxygen and $\mathrm{pH}$ dynamics}

In the light, the zooxanthellae photosynthesis resulted in a build-up of $\mathrm{O}_{2}$ in the tissue of up to $250 \%$ air saturation and a tissue $\mathrm{pH}$ of up to 8.6 , i.e. $0.7 \mathrm{pH}$ units above the $\mathrm{pH}$ value of the overlying seawater, due to intense $\mathrm{CO}_{2}$ fixation (Figs. 1 \& 2). In the dark, $\mathrm{O}_{2}$ was depleted by the polyp and zooxanthellae respiration, and almost anoxic ( $<2 \%$ air saturation) conditions were found in the coral tissue, which now had a low $\mathrm{pH}$ of 7.3 to 7.4 (Fig. 2B). Both $\mathrm{O}_{2}$ and $\mathrm{pH}$ profiles demonstrated the presence of a 200 to $300 \mu \mathrm{m}$ thick DBL that separated the coral tissue and the overlying flowing seawater.

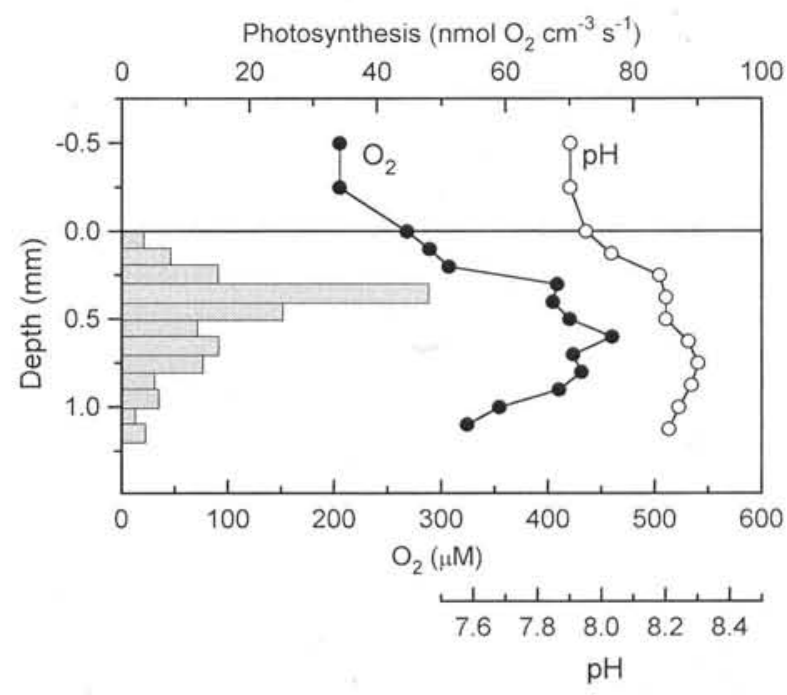

Fig. 1. Acropora sp. Depth profiles of $\mathrm{O}_{2}, \mathrm{pH}$ and gross photosynthesis (bars) in the tissue of a branched stony coral sampled from 5 to $6 \mathrm{~m}$ water depth. Incident photon irradiance (400 to $700 \mathrm{~nm}$ ) was $535 \mu$ Ein $\mathrm{m}^{-2} \mathrm{~s}^{-1}$ 


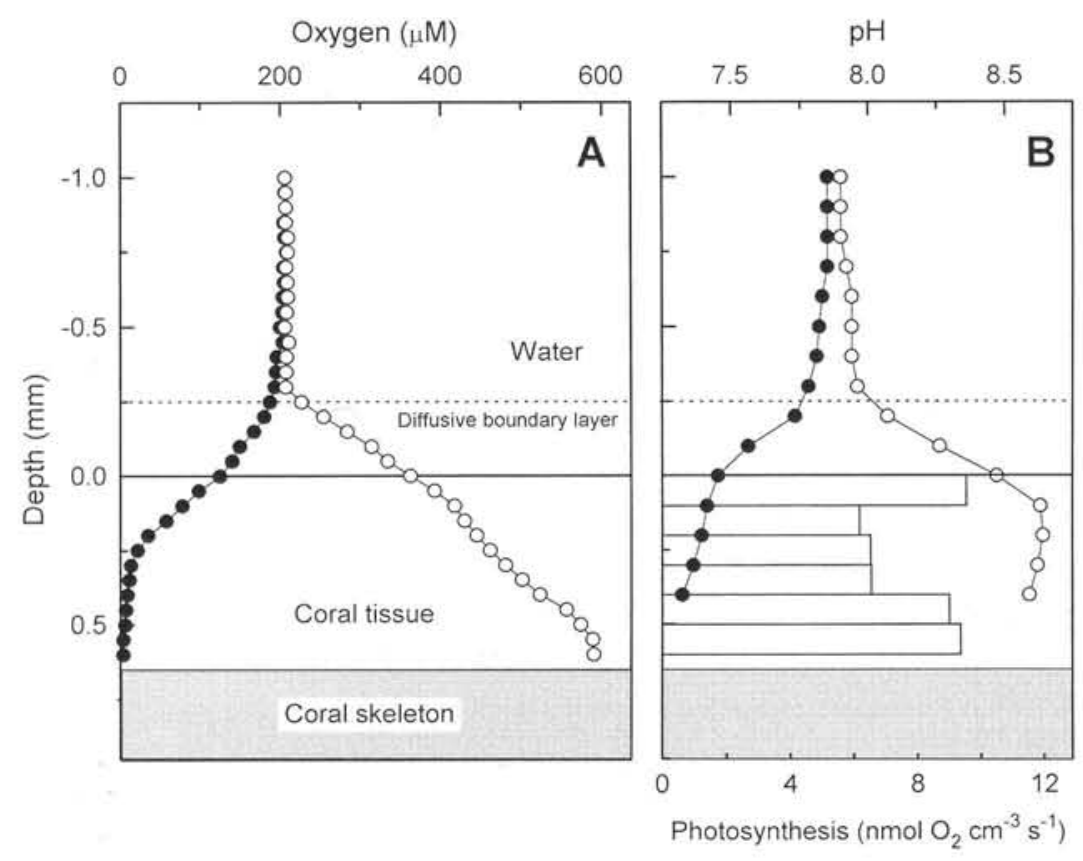

Fig. 2. Favia sp. Depth profiles of (A) $\mathrm{O}_{2}$ and (B) gross photosynthesis and $\mathrm{pH}$ in the tissue of a stony coral sampled from 5 to $6 \mathrm{~m}$ water depth. (•) Profiles measured in darkness; (O) profiles measured at an incident photon irradiance of $350 \mu$ Ein $\mathrm{m}^{-2} \mathrm{~s}^{-1}$. Photosynthetic rates are indicated by bars for every $0.1 \mathrm{~mm}$ interval in the coral tissue (flow velocity was 5 to $6 \mathrm{~cm} \mathrm{~s}^{-1}$ )

decreased with increasing DBL thickness, and anaerobic conditions were reached in stagnant water.

During experimental light-dark cycles, the $\mathrm{O}_{2}$ concentration and $\mathrm{pH}$ of the coral tissue exhibited large variations. The $\mathrm{O}_{2}$ concentration in the upper $0.1 \mathrm{~mm}$ tissue layer of a Favia sp. coral started to decrease immediately after the onset of darkness and changed from $240 \%$ air saturation to $<2 \%$ saturation in $<5 \mathrm{~min}$ (Fig. $4 \mathrm{~A}$ ). Oxygen started to build up as soon as the light was turned on again and reached $>100 \%$ air saturation in $<1 \mathrm{~min}$. The $\mathrm{pH}$ in the upper $0.1 \mathrm{~mm}$ exhibited a similar variation to the $\mathrm{O}_{2}$ concentration although the observed changes were slower (Fig. 4B). Variations between a steady-state tissue $\mathrm{pH}$ of 7.3 to 7.4 in darkness and $\mathrm{pH} 8.4$ to 8.5 in light were observed within 5 to $10 \mathrm{~min}$. The surrounding seawater had a pH of 7.9. The steadystate tissue $\mathrm{pH}$ in Favia sp. varied

The thickness of the DBL varied with the flow velocity and increased from a thickness of 200 to $300 \mu \mathrm{m}$ at a flow velocity of 5 to $6 \mathrm{~cm} \mathrm{~s}^{-1}$ to 500 to $600 \mu \mathrm{m}$ at a flow velocity of 1 to $2 \mathrm{~cm} \mathrm{~s}^{-1}$, and to $>1 \mathrm{~mm}$ thickness in stagnant water (Fig. 3, DBL thickness indicated by arrows). The $\mathrm{O}_{2}$ concentration in the coral tissue

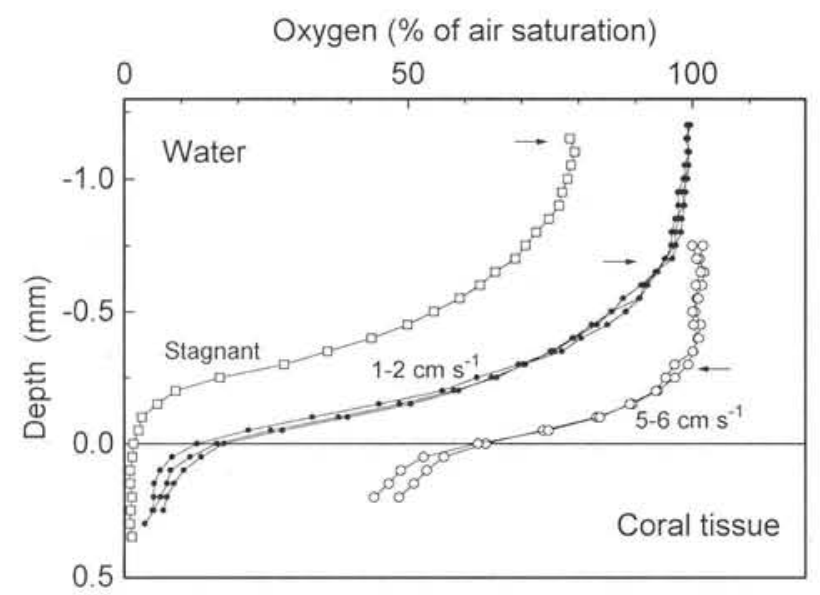

Fig. 3. Favia sp. Oxygen profiles measured in the dark in a coral at different flow velocities of the overlying water. Measurements were made over the tissue connecting 2 ridges of the coral skeleton ( 1 to $2 \mathrm{~mm}$ apart). Arrows indicate DBL. thickness with the incident light intensity (Fig. 5). Largest changes of tissue $\mathrm{pH}$ occurred between darkness and $\sim 100 \mu$ Ein $\mathrm{m}^{-2} \mathrm{~s}^{-1}$ of incident irradiance. Similar dynamic changes of $\mathrm{pH}$ and $\mathrm{O}_{2}$ with light intensity were also found in the polyp tissue of an Acropora sp. branched coral (data not shown; Revsbech \& Jørgensen 1986).

\section{Light intensity and spectral composition}

The scalar irradiance reached a maximum in the outer tissue layers of a high-light adapted Favia sp. coral (Fig. 6). The scalar irradiance maximum reached 125 to $180 \%$ of incident irradiance at 550 to $650 \mathrm{~nm}$ and $>180$ to $200 \%$ at wavelengths $>690 \mathrm{~nm}$. The highest maximum was found in the thin tissue covering coral skeleton ridges. In between ridges the scalar irradiance maximum was less pronounced (maximal values of 100 to $130 \%$ of incident irradiance). At a depth of ca $0.2 \mathrm{~mm}$ below the tissue surface, only light at wavelengths $>690 \mathrm{~nm}$ reached $>100 \%$ of incident irradiance.

Integrated 400 to $700 \mathrm{~nm}$ scalar irradiance reached maxima of up to 160 to $180 \%$ of incident irradiance in the tissue of a high-light adapted Favia sp., while scalar irradiance in a dark-colored, low-light adapted 

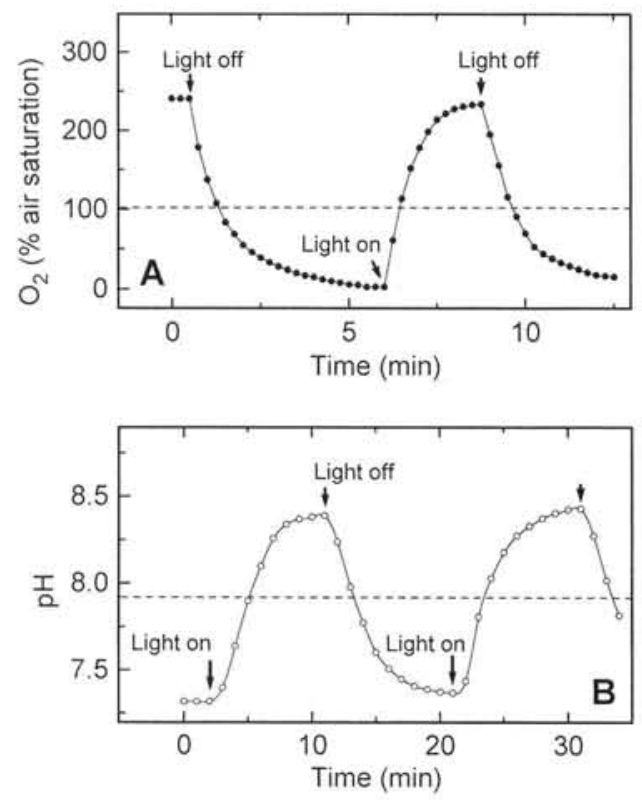

Fig. 4. Favia sp. (A) Oxygen and (B) $\mathrm{pH}$ variations in the upper $0.1 \mathrm{~mm}$ of the tissue of coral during light-dark shifts. Incident photon irradiance was $350 \mu \mathrm{Ein} \mathrm{m}^{-2} \mathrm{~s}^{-1}$. Dotted lines: $\mathrm{O}_{2}$ content and $\mathrm{pH}$ of the ambient seawater

Favia sp. reached maxima of up to 130 to $140 \%$ of incident irradiance in the upper 0.0 to $0.1 \mathrm{~mm}$ of the tissue (data not shown).

The scalar irradiance spectra exhibited distinct minima at absorption wavelengths of the major zooxanthellae chlorophylls (chl $a$ at 675 to $680 \mathrm{~nm}$, chl $c$ at 625 to $640 \mathrm{~nm}$ ). A shoulder in the spectra around $590 \mathrm{~nm}$ was probably due to a secondary absorption maximum of chl $c$ (Shibata \& Haxo 1969). Carotenoids caused a broad absorption band at 450 to $550 \mathrm{~nm}$ with shoulders in the spectra at 480 to $490 \mathrm{~nm}$ and at 540 to

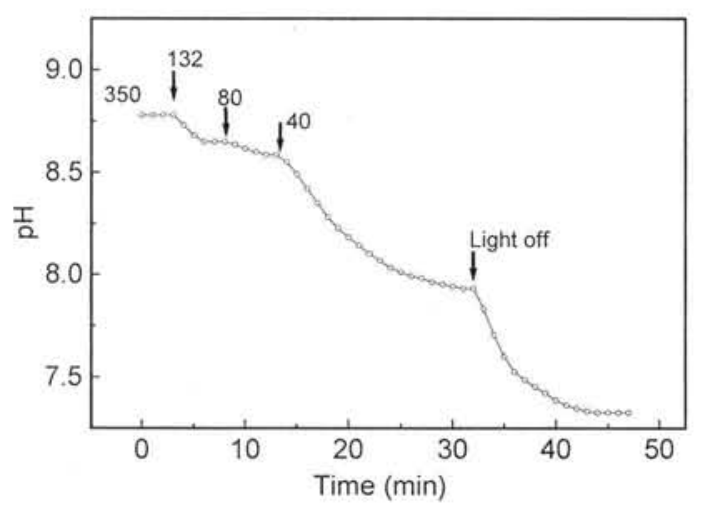

Fig. 5. Favia sp. Changes of $\mathrm{pH}$ in the outer $0.1 \mathrm{~mm}$ of coral tissue with changing light intensities. Numbers in graph are incident photon irradiance $\left(\mu \mathrm{Ein} \mathrm{m}^{-2} \mathrm{~s}^{-1}\right)$

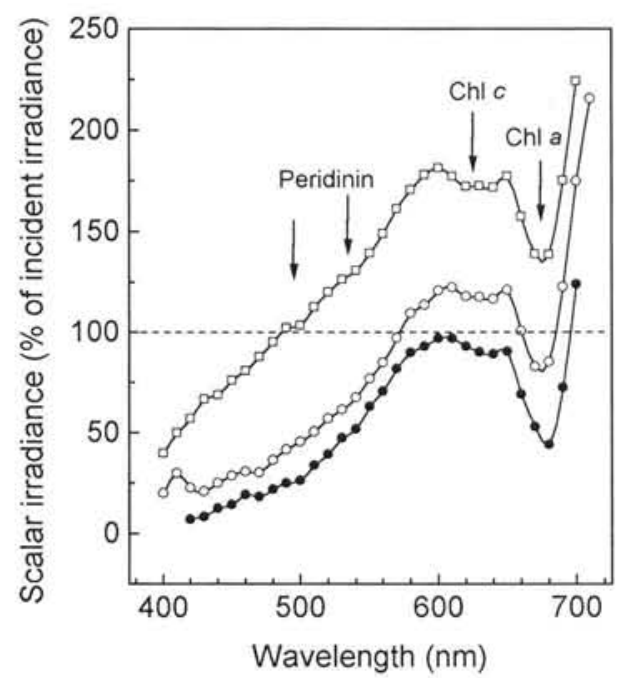

Fig. 6. Favia sp. Spectral scalar irradiance $(400$ to $700 \mathrm{~nm})$ in corals ( $\%$ of incident irradiance at the tissue surface) collected from 5 to $6 \mathrm{~m}$ depth, measured ( $\square$ ) at the tissue surface on top of a skeleton ridge, $(0)$ in between 2 ridges, and $(\bullet) 0.1$ to $0.2 \mathrm{~mm}$ below the tissue surface

$550 \mathrm{~nm}$ indicating the presence of the dinoflagellate carotenoid peridinin (cf. Halldal 1968, Shibata \& Haxo 1969).

\section{Spatial heterogeneity}

The distribution of gross photosynthetic activity was measured in a transect across a single Favia sp. polyp (Fig. 7). Photosynthetic activity varied from $<5 \mathrm{nmol} \mathrm{O}_{2}$ $\mathrm{cm}^{-3} \mathrm{~s}^{-1}$ in the relatively flat area surrounding the mouth opening of the contracted polyp up to $32 \mathrm{nmol}$ $\mathrm{O}_{2} \mathrm{~cm}^{-3} \mathrm{~s}^{-1}$ in the tissue covering the inner ridges of coral skeleton. High activity was also found in the tissue of the oral disk.

\section{Action spectra}

The most distinct feature of the action spectrum of zooxanthellae photosynthesis in the tissue of Acropora sp. was the relatively broad maximum at 620 to $680 \mathrm{~nm}$ due to $\mathrm{chl} a$ (peak at $675 \mathrm{~nm}$ and shoulder at $620 \mathrm{~nm}$ ) and chl $c$ (small peak at 580 to $590 \mathrm{~nm}$ and shoulder at 640 to $650 \mathrm{~nm}$ ) (Fig. 8). In the blue part of the spectrum, photosynthetic activity due to chl a absorption at 430 to $450 \mathrm{~nm}$, chl $c$ absorption at 460 to $470 \mathrm{~nm}$, and peridinin absorption at 490 to $540 \mathrm{~nm}$ was found as shoulders or small peaks in the action spectrum (photopigment absorption wavelengths according to Halldal 1968, Shibata \& Haxo 1969, Prézelin et al. 1976). 

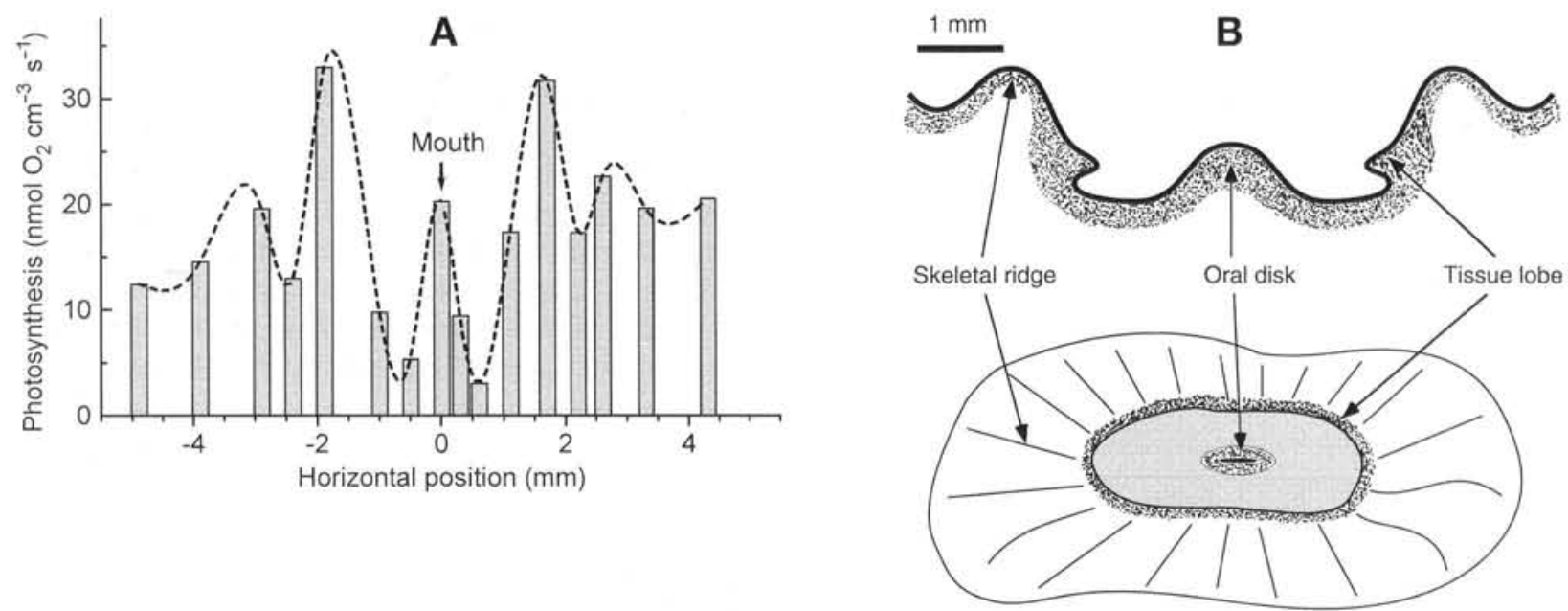

Fig. 7. Favia sp. (A) Distribution of gross photosynthesis in the upper $0.1 \mathrm{~mm}$ of coral tissue in a transect over a single contracted polyp. Bars: measured gross photosynthesis; dashed line: a cubic spline through the data points. (B) A schematic drawing of a Favia sp. polyp. Horizontal position is given in $\mathrm{mm}$ distance from the mouth opening of the polyp

\section{Photosynthesis versus irradiance}

The gross photosynthesis of the zooxanthellae in an Acropora sp. as a function of the incident integrated 400 to $700 \mathrm{~nm}$ irradiance (PAR) is shown in Fig. 9. The hyperbolic tangent function of Jassby \& Platt (1976) was fitted to the $P$ vs $I$ data by a nonlinear least-square Levenberg-Marquardt algorithm (Origin 3.0, MicroCal Software, Inc.) giving an initial slope $\alpha=0.04$ and a maximum photosynthetic rate $P_{\max }=11 \mathrm{nmol} \mathrm{O}_{2} \mathrm{~cm}^{-3}$

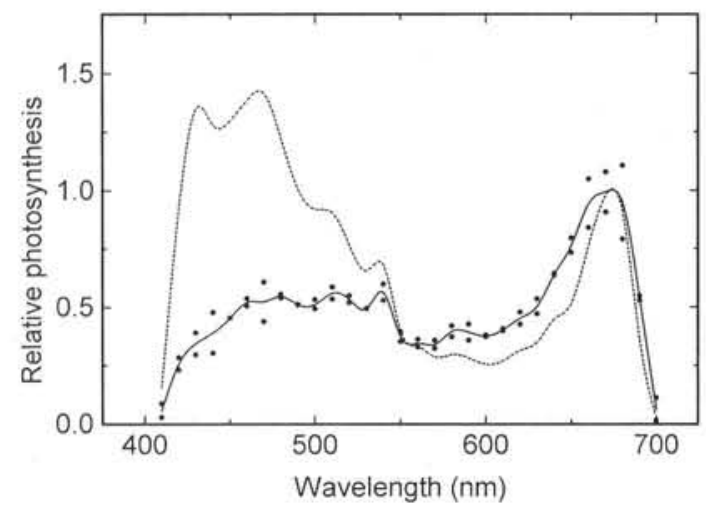

Fig. 8. Acropora sp. Action spectrum of zooxanthellae photosynthesis in coral tissue. Measured rates were recalculated for each wavelength to a quantum irradiance of $100 \mu \mathrm{Ein} \mathrm{m}^{-2} \mathrm{~s}^{-1}$ and subsequently normalised to the rate measured repeatedly at $675 \mathrm{~nm}$. Solid line: a cubic spline curve through the average of 2 action spectra (•) with incident irradiance as the light intensity parameter. Dashed line: action spectrum obtained by recalculation with scalar irradiance as the light intensity parameter $\mathrm{s}^{-1}$. The irradiance at the onset of light saturation, $I_{k}$, could thus be calculated as $I_{k}=P_{\max } / \alpha=275 \mu \mathrm{Ein} \mathrm{m}^{-2}$ $\mathrm{s}^{-1}$. The hyperbolic tangent function has been shown to give the best fit to $P$ vs $I$ data for corals (Chalker 1981).

Another $P$ vs $I$ curve was measured in a Favia sp. (Fig. 10). When the gross photosynthesis $P$ was plotted against the incident irradiance $E_{\mathrm{d}}$, we obtained an initial slope $\alpha=0.09$, a maximum photosynthetic rate $P_{\max }=13.65 \mathrm{nmol} \mathrm{O}_{2} \mathrm{~cm}^{-3} \mathrm{~s}^{-1}$, and an onset of light saturation at $I_{k}=152 \mu$ Ein $\mathrm{m}^{-2} \mathrm{~s}^{-1}$ from the fitted hyperbolic tangent function. If $P$ was plotted against the

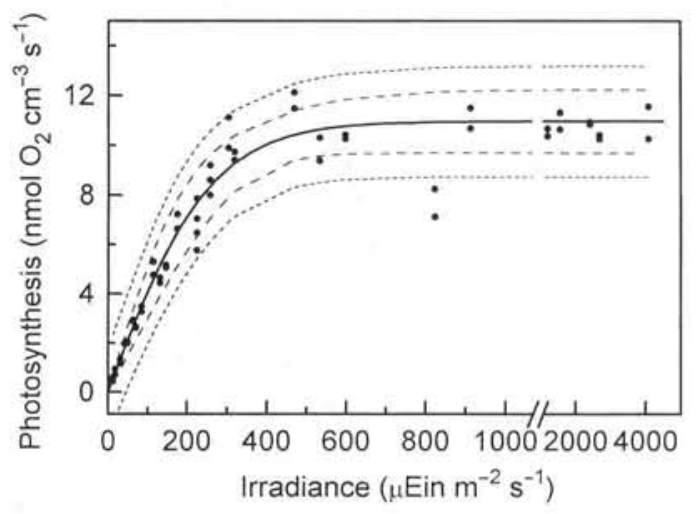

Fig. 9. Acropora sp. Gross zooxanthellae photosynthesis vs incident 400 to $700 \mathrm{~nm}$ quantum irradiance $\left[E_{\mathrm{d}}(\mathrm{PAR})\right]$ in coral tissue. Solid line: a curve fit of the hyperbolic tangent function (Jassby \& Platt 1976) to the data $\left(\mathrm{r}^{2}=0.987, \chi^{2}=0.330\right)$. Dashed and dotted lines: $95 \%$ confidence and prediction intervals, respectively 


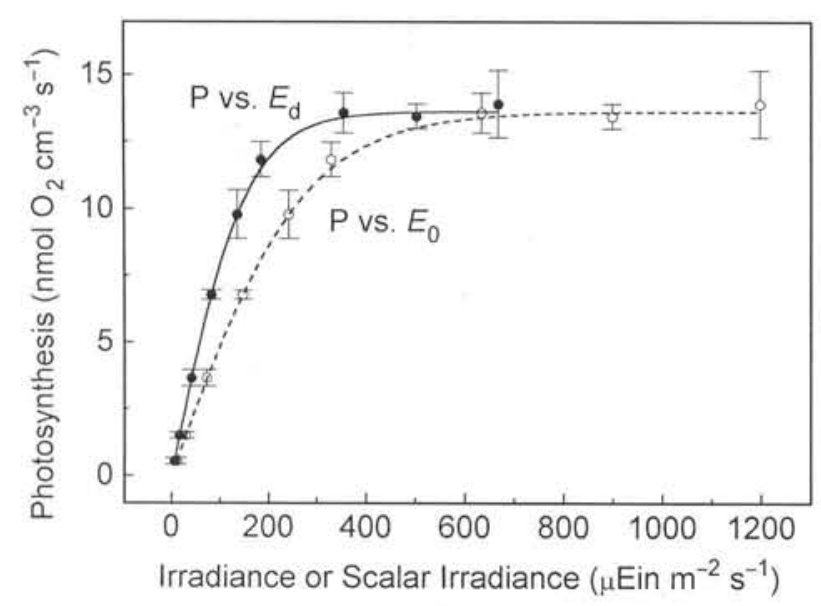

Fig. 10. Favia sp. Gross zooxanthellae photosynthesis vs incident 400 to $700 \mathrm{~nm}$ quantum irradiance, $E_{\mathrm{d}}(\bullet)$, and vs incident quantum scalar irradiance, $E_{0}(0)$, in coral tissue. Solid and dashed lines: curve fits of the hyperbolic tangent function (Jassby \& Platt 1976) to the $P$ vs $E_{\mathrm{d}}$ and $P$ vs $E_{0}$ data, respectively $\left(\mathrm{r}^{2}=0.999, \chi^{2}=0.078\right)$

scalar irradiance (assuming a scalar irradiance of $180 \%$ of the incident irradiance) the respective parameters from the curve fit were $\alpha=0.05, P_{\max }=$

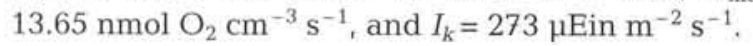

\section{Net photosynthesis and respiration}

The $\mathrm{O}_{2}$ budget for the coral tissue of Favia sp. in the dark and at a saturating irradiance of $350 \mu \mathrm{Ein} \mathrm{m}^{-2} \mathrm{~s}^{-1}$ is shown in Table 1. The fluxes of $\mathrm{O}_{2}$ across the DBL into the tissue (dark respiration) and out of the tissue (net photosynthesis) were calculated from the dark and light steady-state $\mathrm{O}_{2}$ profiles respectively, shown in Fig. 2. Total gross photosynthesis was calculated by depth integration. Respiration was found to be $0.055 \mathrm{nmol} \mathrm{O}_{2} \mathrm{~cm}^{-2} \mathrm{~s}^{-1}$ in the dark and $0.366 \mathrm{nmol} \mathrm{O}_{2}$ $\mathrm{cm}^{-2} \mathrm{~s}^{-1}$ in the light, and thus accounted for 11 and $77 \%$, respectively, of the $\mathrm{O}_{2}$ production by gross photosynthesis.

Table 1. Favia sp. Oxygen budget in coral tissue calculated from data in Fig. 2. Photosynthesis and respiration in $\mathrm{nmol} \mathrm{O}_{2}$

$$
\mathrm{cm}^{-2} \mathrm{~s}^{-1}
$$

\begin{tabular}{|c|c|c|c|c|}
\hline & \multicolumn{2}{|c|}{ Photosynthesis } & \multirow[t]{2}{*}{ Respiration } & \multirow{2}{*}{$\begin{array}{c}\% \text { of gross } \\
\text { photosynthesis }\end{array}$} \\
\hline & Gross & Net & & \\
\hline Dark & - & - & 0.055 & 11.7 \\
\hline Light $^{\mathrm{a}}$ & 0.471 & 0.105 & 0.366 & 77.7 \\
\hline \multicolumn{5}{|c|}{ ancident irradiance $=350 \mu$ Ein $\mathrm{m}^{-2} \mathrm{~s}^{-1}$} \\
\hline
\end{tabular}

\section{DISCUSSION}

\section{Dynamics of the chemical microenvironment}

The high metabolic activity of zooxanthellae and the surrounding polyp tissue, coupled with diffusion as the major exchange process with the surroundings, creates a dynamic microenvironment in the coral tissue (Figs. 1 to 5). At irradiances of $>100 \mu \operatorname{Ein~m}^{-2} \mathrm{~s}^{-1}$, the photosynthetic activity of the zooxanthellae resulted in supersaturation with respect to $\mathrm{O}_{2}(>250 \%$ air saturation), and to alkaline conditions within the coral tissue $(>0.5 \mathrm{pH}$ units above the ambient seawater level) due to $\mathrm{CO}_{2}$ fixation by the microalgae. Our results show that the tissue of Favia sp. and Acropora sp, living in shallow water is supersaturated with $\mathrm{O}_{2}$ during most of the day, thus supporting earlier observations reported in the literature (e.g. Crossland \& Barnes 1977, Shick 1990, Patterson et al. 1991, Shashar et al. 1993).

In the dark, coral respiration depleted $\mathrm{O}_{2}$ to nearanaerobic conditions ( $<5 \%$ air saturation), and a low $\mathrm{pH}$ ( $>0.5 \mathrm{pH}$ units below seawater $\mathrm{pH}$ ) was found throughout the tissue. The change from a steady-state light to a steady-state dark situation or vice versa occurred within minutes after a change in the light field (Figs. 4 \& 5). This demonstrated the dynamic balance between respiration and photosynthesis, and consequently how the chemical microenvironment in the coral is regulated by fluctuations in light intensity (e.g. shading by clouds passing the sun). The $\mathrm{pH}$ changes were slower (5 to $10 \mathrm{~min}$ ) than the $\mathrm{O}_{2}$ variations ( $<1 \mathrm{~min})$ due to the relatively large buffering capacity of the bicarbonate pool in the tissue and surrounding seawater. Although no light-dark cycle measurements in the tissue were presented, similar dynamics of $\mathrm{O}_{2}$ and $\mathrm{pH}$ have been found in the DBL above a Favia favus coral (Shashar \& Stambler 1992), in the skeleton of the coral Porites compressa (Shashar et al. 1993) and in the symbiotic foraminiferan Globigerinoides sacculifer (Jørgensen et al. 1985).

\section{Diffusive boundary layers and diffusion geometry}

The DBL and its function as a diffusion barrier for solute exchange between the coral tissue and the surrounding turbulent water is discussed by Patterson et al. (1991) and Patterson (1992). The presence of a DBL over the coral tissue was evident from the measured steady-state microprofiles of $\mathrm{O}_{2}$ and $\mathrm{pH}$ in Favia sp. (Figs. $2 \& 3$ ). As there is no significant production or consumption of $\mathrm{O}_{2}$ within the DBL, the 1-dimensional concentration gradients of $\mathrm{O}_{2}$ should be linear within the DBL with a gradual transition at the upper DBL boundary to the $\mathrm{O}_{2}$ concentration of the overlying tur- 
bulent water (Jørgensen \& Des Marais 1990). The DBL thickness can be found by extrapolation of the linear DBL gradient out to the bulk concentration (Jørgensen \& Revsbech 1985). In the corals, DBL thickness increased with decreasing flow velocity resulting in a higher mass transfer resistance and thus a lower $\mathrm{O}_{2}$ concentration in the tissue (Fig. 3). Coral dark respiration was thus shown to depend on, and even be limited by, the diffusive supply of $\mathrm{O}_{2}$ through the DBL.

Despite a lower $\mathrm{O}_{2}$ concentration in the coral tissue and a thicker DBL, the diffusive flux of $\mathrm{O}_{2}$ calculated from Fick's first law for 1-dimensional diffusion (Eq. 1) increased from $0.092 \mathrm{nmol} \mathrm{O}_{2} \mathrm{~cm}^{-2} \mathrm{~s}^{-1}$ at 5 to $6 \mathrm{~cm} \mathrm{~s}^{-1}$ to $0.102 \mathrm{nmol} \mathrm{O}_{2} \mathrm{~cm}^{-2} \mathrm{~s}^{-1}$ at 1 to $2 \mathrm{~cm} \mathrm{~s}^{-1}$ flow velocity. Most of our microelectrode measurements were done between ridges of coral skeleton ( 1 to $2 \mathrm{~mm}$ apart) covered with coral tissue. At moderate flow velocities ( 5 to $6 \mathrm{~cm} \mathrm{~s}^{-1}$ ), the DBL thickness was $\sim 200 \mu \mathrm{m}$. The effect on the diffusion geometry of the surrounding ridge tissue 0.5 to $1 \mathrm{~mm}$ away was thus negligible, and solute transport between the coral tissue and the overlying water could be described by 1-dimensional diffusion. The DBL thickness increased to $\sim 600 \mu \mathrm{m}$ at 1 to $2 \mathrm{~cm} \mathrm{~s}^{-1}$ and a 3-dimensional, tubular geometry would be required to adequately describe the diffusion geometry. The $\mathrm{O}_{2}$ profiles measured above the tissue at low flow velocities were thus affected by the $\mathrm{O}_{2}$ consumption of the surroundings, and 1-dimensional flux calculations were no longer valid. This effect of diffusion geometry was even more pronounced under stagnant conditions (Fig. 3), where $\mathrm{O}_{2}$ in the 1 to $2 \mathrm{~mm}$ thick layer of overlying water was depleted by the surroundings along the measurement direction, and where the $\mathrm{O}_{2}$ profile exhibited a curvature characteristic of a 3-dimensional diffusion geometry (cf. Crank 1975, Jørgensen et al. 1985).

Shashar et al. (1993) studied the DBL over single Favia favus and Stylophora pistillata coral polyps and demonstrated how the DBL follows polyp morphology. Both in stagnant water and at a flow velocity of $5 \mathrm{~cm} \mathrm{~s}^{-1}$ the thickest DBL (1 to $5 \mathrm{~mm}$ ) was found over the central oral disk of the polyp, while 1 to $2 \mathrm{~mm}$ thick DBLs were found near the skeleton ridges of the investigated corals. The DBL thickness and the dimensions of the coral polyps (1 to $10 \mathrm{~mm}$ polyp width) reported by Shashar et al. (1993) indicate that at least the central part of the polyps exhibited a 3-dimensional diffusion geometry under the given experimental conditions. Equations applicable to tubular diffusion geometries in corals were described by Patterson (1992).

The presence of a microsensor may also impose changes in the locally measured diffusive flux by compressing the DBL, thus resulting in a steeper concentration gradient across the DBL (Glud et al. 1994). For $5 \mu \mathrm{m}$ thin microelectrodes the compression of the DBL was found to increase the $\mathrm{O}_{2}$ flux by $\sim 10$ to $60 \%$ in various marine sediments relative to measurements in which the microelectrode was inserted from below the sediment surface. The compression effect by the microelectrode was ascribed to perturbations of the local flow velocity field, which were, however, independent of the flow velocity over a flat surface. In a recent study of microbial mats, it was shown that the boundary layer compression only showed significant effects on the $\mathrm{O}_{2}$ concentration in biofilms with a smooth and homogeneous surface, while no effect was found when the surface was irregular (Lorenzen et al. 1994). When present, the compression effect did not affect the gross photosynthesis measured by the lightdark shift technique. The extent of DBL compression in our coral measurements and how this effect interacts with the diffusional geometry within coral polyps awaits combined high-resolution measurements of the DBL and the flow field around corals under more defined hydrodynamic conditions. One-dimensional diffusion equations should be used with care in corals, which exhibit a complex polyp morphology that interacts with the water flow and leads to flow-dependent differences in diffusion geometry within the polyp.

The DBL for other solutes like $\mathrm{CO}_{2}, \mathrm{Ca}^{2+}$ and nutrients will be similar to the oxygen DBL in corals (Patterson et al. 1991, Patterson 1992). Water motion and its effect on DBL thickness is thus a crucial factor in the overall regulation of coral metabolism and increased flow velocity has been shown to increase respiration, photosynthesis and calcification in corals (Dennison \& Barnes 1988, Barnes \& Chalker 1990, Patterson et al. 1991).

\section{Photosynthesis and light-enhanced respiration}

In comparison with traditional gas-exchange techniques, a major advance of the $\mathrm{O}_{2}$ microelectrode light-dark shift technique for photosynthesis measurements is the independence of the measured gross photosynthetic rate from respiration (Revsbech et al. 1981, Revsbech \& Jørgensen 1983, Glud et al. 1992). The high spatial and temporal resolution of the method thus enabled us to measure directly gross photosynthesis of the zooxanthellae while exposed to the chemical and physical gradients present within the coral tissue (Figs. 1, 2, 7 to 10). Gross photosynthesis of corals is traditionally measured indirectly as the sum of dark respiration and net photosynthesis under the assumption that dark respiration is identical to the respiration rate in light (Muscatine et al. 1981, Edmunds \& Davies 1988, Muscatine 1990).

The respiratory activity of the coral tissue in the light cannot be inferred from gas-exchange or ${ }^{14} \mathrm{C}$ measure- 
ments (Muscatine 1990) but can now be obtained from $\mathrm{O}_{2}$ microelectrode measurements. Steady-state $\mathrm{O}_{2}$ profiles measured in the coral express the net outcome of photosynthesis, respiration and diffusive transport. Thus, net photosynthesis in the coral tissue can be calculated from steady-state $\mathrm{O}_{2}$ concentration profiles as the diffusive flux of $\mathrm{O}_{2}$ out of the coral tissue in the light (Table 1). An analogous calculation of the diffusive flux into the coral tissue from steady-state $\mathrm{O}_{2}$ profiles in the dark yields the dark respiration of the coral. These measures of net photosynthesis and dark respiration, although point measurements, are comparable to the data traditionally obtained with gas-exchange studies of coral photosynthesis and respiration (e.g. Crossland \& Barnes 1977, Muscatine 1980). The difference between the depth-integrated gross photosynthesis measured by the light-dark shift technique and the net photosynthesis calculated from steady-state $\mathrm{O}_{2}$ profiles yields a measure of the total respiration of the coral tissue in the light (Jensen \& Revsbech 1989). We used this approach in a Favia sp. coral and found the coral respiration under saturating light conditions to be 6 times higher than the dark respiration (Table 1). A higher coral respiration in light has been postulated from observations of a post-illumination enhancement of respiration in corals (Edmunds \& Davies 1988), a higher dark respiration in light-adapted vs shadeadapted corals (Porter et al. 1984), and from measurements of higher coral dark respiration in hypoxic water (Shick 1990). To our knowledge, we present here the first data of daytime respiration measured in illuminated corals.

The high $\mathrm{O}_{2}$ concentration and low $\mathrm{CO}_{2}$ concentration (indicated by the high $\mathrm{pH}$ ) found in the illuminated coral tissue create favorable conditions for photorespiration, i.e. the $\mathrm{O}_{2}$ consumption caused by a detoxification of glycollate produced by the oxygenase activity of the enzyme ribulose bisphosphate carboxylase (Ogren 1984, Beardall 1989). Although the presence of a functional photorespiratory pathway in zooxanthellae has been demonstrated, the significance of photorespiration in zooxanthellae is still largely unknown (Muscatine 1990). At present we cannot therefore rule out that part of the enhanced $\mathrm{O}_{2}$ consumption in light is due to photorespiration. Microsensor measurements in corals under experimentally controlled $\mathrm{O}_{2} / \mathrm{CO}_{2}$ ratios similar to the experiments described by Glud et al. (1992) could probably give an estimate of the importance of photorespiration in corals.

Another mechanism for light-enhanced $\mathrm{O}_{2}$ consumption could be a true stimulation of the cell metabolism of zooxanthellae, the host or both, e.g. by organic compounds freshly translocated from the zooxanthellae to the host tissue during photosynthesis (Edmunds \&
Davis 1988). Such a mechanism for light-enhanced respiration has been demonstrated in phytoplankton (Falkowski et al. 1985).

Yet another mechanism causing light-enhanced $\mathrm{O}_{2}$ consumption in corals was demonstrated by Shick (1990), who showed that the dark respiration of corals and other anthozoans was limited by the diffusive supply of $\mathrm{O}_{2}$. This was demonstrated by an enhanced dark respiration when corals were incubated in hyperoxic water. For the branched coral Stylophora pistillata up to $20 \%$ higher dark respiration was observed in hyperoxic water relative to the respiration in air-saturated water. The diffusion limitation of dark respiration is caused by the presence of a DBL (Patterson 1992, Shashar et al. 1993, Figs. 2 \& 3 in this study). By using hyperoxic water in the dark incubations, the effect of the DBL on $\mathrm{O}_{2}$ supply was alleviated and respiration thus no longer $\mathrm{O}_{2}$ limited. A similar alleviation of the diffusion limitation of $\mathrm{O}_{2}$ was postulated to occur at daytime, due to the internal $\mathrm{O}_{2}$ production by zooxanthellae photosynthesis. Our data confirm this hypothesis by showing the presence of hyperoxic conditions in the coral tissue, which lead to a net efflux of $\mathrm{O}_{2}$ to the overlying water in light (Fig. 2).

The observed stimulation of coral respiration in the light, most probably by a combination of the abovementioned mechanisms, has profound consequences for the calculation of energy and carbon budgets in corals. Our data indicate a potential daytime respiration 6 times higher than the dark respiration (Table 1). Edmunds \& Davies (1988) and Shick (1990) report a 10 to $60 \%$ higher dark respiration either after previous illumination or under hypoxic conditions. Under the traditional assumption of equal respiration in the dark and the light, daytime respiration is consequently underestimated and will result in a corresponding underestimation of gross photosynthesis. The quantification of daytime respiration thus seems crucial for future studies of carbon and energy budgets in corals.

\section{Light and photosynthesis}

Apart from the chemical microenvironment, which is highly dependent on diffusional exchange processes, the key parameters for photosynthesis regulation are the intensity and spectral composition of the light field surrounding the zooxanthellae. The light field available for the zooxanthellae in the tissue differed strongly from the incident irradiance due to the combined action of multiple scattering and absorption, resulting in a wavelength-dependent local maximum of the spherically integrated quantum flux (i.e. scalar irradiance) in the upper tissue layers (Fig. 6). Similar results have been found in studies of the light field in 
plant tissue, sediments and microbial mats (e.g. Vogelmann \& Björn 1986, Jørgensen \& Des Marais 1988, Kühl \& Jørgensen 1992, Kühl et al. 1994a, b).

The mechanism behind the observed local maximum of scalar irradiance relative to incident irradiance can be explained in terms of multiple scattering and diffuse reflection of light within the coral tissue and from the surrounding coral skeleton, which is not taken into account in the measurement of incident downwelling irradiance. Diffuse reflection from the coral skeleton is definitely an important component of the scalar irradiance maximum. The light field exhibited horizontal heterogeneity at the level of a single coral polyp and the highest values of scalar irradiance were found on ridges of coral skeleton covered with the thinnest tissue layers (Fig. 6). Furthermore, if the refractive index of the coral tissue is higher than that of water, diffuse backscattered light can be internally reflected at the tissue-water interface, where collimated light is continuously incident. Light can thus enter more easily into the tissue from the water than it can escape back into the water. The significance of such an internal reflection mechanism for the observed scalar irradiance maximum has been demonstrated in animal tissue by Anderson et al. (1989).

Multiple scattering increases the pathlength of photons per vertical distance traversed. The increased pathlength due to multiple scattering is thus equivalent to a longer residence time of photons within a given layer of the optically dense coral tissue, which results in a higher photon flux density close to the tissue surface where collimated light is continuously incident from above. The amplification effect of the increased pathlength on the scalar irradiance at the tissue surface will be most pronounced at wavelengths outside the major absorption regions of coral photopigments, e.g. infrared light, while in the spectral regions of maximal photopigment absorption the increased pathlength due to multiple scattering leads to more efficient light absorption. Scattering thus also leads to an amplification of the spectral differences between regions of low and high absorption, respectively. A more detailed discussion of the optical mechanisms behind the observed scalar irradiance maximum is beyond the scope of this study and can be found elsewhere (e.g. Vogelmann \& Björn 1986, Anderson et al. 1989, Kühl \& Jørgensen 1994).

The properties of the microscale light field experienced by the zooxanthellae must be taken into account in studies of their photophysiology. The zooxanthellae live in a strongly scattering environment and as such the relevant light intensity measure for the symbiont photosynthesis is scalar irradiance rather than incident irradiance (Weinberg 1976, Kirk 1983). We measured the action spectrum of zooxanthellae photosynthesis in
Acropora sp. as a function of the incident collimated light, i.e. the downwelling irradiance (Fig. 8). The zooxanthellae do, however, also receive a significant amount of scattered light from their surroundings and a true action spectrum of the microalgae is thus related to the scalar irradiance (Jørgensen et al. 1987). The contribution of scattered light, which was not taken into account in the recalculation of photosynthetic rates to the same incident light intensity ('Material and methods'), will be wavelength dependent (Fig. 6) thus leading to relatively more scattered light at wavelengths outside the major absorption regions of the coral photopigments. The action spectrum calculated with the downwelling irradiance as the light intensity measure does not take this effect into account and will thus be distorted. This might be the explanation for the relative low photosynthetic activity in the blue region of chl a absorption in the action spectrum presented here (solid curve in Fig. 8). In order to estimate the degree of distortion we recalculated the action spectra using a scalar irradiance spectrum obtained in a Favia sp. (dotted curve in Fig. 8). The recalculated action spectrum shows a much higher photosynthetic activity in the blue part of the spectrum and is similar to action spectra presented for isolated zooxanthellae (Halldal 1968) and planktonic dinoflagellates (e.g. Prézelin et al. 1976).

The $P$ vs $I$ curve and derived parameters of zooxanthellae photosynthesis also depend on the measure of light intensity. If photosynthesis in Favia sp. was plotted against scalar irradiance $E_{0}$ instead of downwelling irradiance $E_{\mathrm{d}}$, the $P$ vs $E_{0}$ curve (dotted curve in Fig. 10) exhibited a lower initial slope than the $P$ vs $E_{\mathrm{d}}$ curve (solid curve in Fig. 10). The maximum photosynthetic rate is independent of the choice of light intensity parameter, and thus the $P$ vs $E_{0}$ curve exhibited a higher onset of light saturation $\left(I_{k}=273 \mu \operatorname{Ein~m}^{-2} \mathrm{~s}^{-1}\right)$ than the $P$ vs $E_{\mathrm{d}}$ curve $\left(I_{k}=152 \mu\right.$ Ein $\left.\mathrm{m}^{-2} \mathrm{~s}^{-1}\right)$. This effect of scalar irradiance on the parameters of photosynthetic performance is probably an overestimate due to the anticipation of a scalar irradiance of $180 \%$ of incident irradiance throughout the visible spectrum. Nevertheless, our data indicate that $P$ vs $E_{\mathrm{d}}$ curves measured in photosynthetic communities where light scattering is significant exhibit higher initial slopes and thus result in lower $I_{k}$-values for photosynthesis than equivalent calculations based on $P$ vs $E_{0}$ curves. Preferentially, studies of the photosynthetic performance of zooxanthellae and e.g. photosynthetic microorganisms in sediments and biofilms should thus take scattered light into account by measurements of scalar irradiance.

Although the coral tissue was supersaturated with $\mathrm{O}_{2}$ in light, the $P$ vs $I$ curves in both Acropora sp. and Favia sp. exhibited no indications of photoinhibition at 
high light intensities (Figs. $9 \& 10$ ). High levels of the protective enzymes superoxide dismutase, catalase, and ascorbate peroxidase are present in coral tissue (Lesser \& Shick 1989, Shashar \& Stambler 1992). An efficient protection against toxic effects of high $\mathrm{O}_{2}$ concentrations in the tissue (i.e. photooxidation) by the enzymes mentioned is probably a major mechanism behind the absence of photoinhibition often observed in shallow water corals and associated algal communities (Carpenter 1985, Falkowski et al. 1990). Another important mechanism is the presence of high levels of protective pigments, especially UV-absorbing compounds in corals, which protect against both direct UV damage and synergistic effects of UV and high $\mathrm{O}_{2}$ in the coral (e.g. Shibata 1969, Falkowski et al. 1990, Drollet et al. 1993, Kinzie 1993).

The previously mentioned variation of the DBL (Fig. 3) (Shashar et al. 1993) and the observed differences in the light field within single polyps (Fig. 6) may lead to a spatial heterogeneity of photosynthesis and respiration. The spatial variation of e.g. photosynthetic activity within a single polyp (Fig. 7) might, however, also result from differences in zooxanthellae densities in various parts of the polyp. Thus a direct comparison of microsensor measurements with whole-colony respiration and photosynthesis obtained by the $\mathrm{O}_{2}$ exchange techniques would therefore require a more detailed mapping of the DBL and the light field together with measurements of photosynthesis, respiration and zooxanthellae densities under defined illumination and hydrodynamic conditions.

In conclusion, we found the regulation of coral physiology to be strongly dependent on the gradient microenvironment of the zooxanthellae and the polyp tissue. The chemical microenvironment results from combined host and symbiont metabolism and diffusional transport. These are regulated by a flow-dependent DBL. In the dark, coral respiration is limited by the diffusive supply of $\mathrm{O}_{2}$ from the surrounding water through the DBL, while in the light the zooxanthellae photosynthesis results in hyperoxic conditions in the coral tissue and thus provides an internal supply of $\mathrm{O}_{2}$ for coral respiration. Coral respiration in the light is much higher than dark respiration, although photorespiration might account for a part of the observed difference. The photosynthetic performance of the zooxanthellae is highly dependent on the coral tissue light field. Scattered light is important for the zooxanthellae and results in a higher light intensity and a different spectral composition of light in the coral tissue than expected from the incident irradiance. Scalar irradiance is thus the most relevant light intensity parameter in relation to zooxanthellae photosynthesis.

We found microsensors to be ideal tools for studies of the microenvironmental controls of coral physiology.
Many of the experimental techniques traditionally used in studies of coral photosynthesis and respiration rely on assumptions about the microenvironment of the coral tissue, which can now be tested by direct measurements with microsensors.

Acknowledgements. We thank the staff of the H. Steinitz Marine Biological Laboratory in Eilat, Israel, for their assistance and the access to laboratory facilities during numerous visits. We also thank Nadav Shashar, Razi Wigo and Katharina Fabricius for their help in the laboratory and with the sampling of coral specimens by SCUBA diving. Carsten Lassen, Einar Larsen, Ronnie Glud, Jens Gundersen and Bo Thamdrup are thanked for providing the data acquisition and motor controlling software and hardware. We especially thank Anja Eggers, Gaby Eickert and Anni Glud for the construction of microsensors. Financial support was provided by the Danish Center for Microbial Ecology, the Danish Natural Science Research Council, the Max Planck Society (Germany) and a grant of GSF, Munich, and MOST, Jerusalem, to Y.C.

\section{LITERATURE CITED}

Anderson, R. R., Beck, H., Bruggeman, U., Farinelli, W., Jaques, S. L., Parrish, J. A. (1989). Pulsed photothermal radiometry in turbid media: internal reflection of backscattered radiation strongly influences optical dosimetry. Appl. Optics 28: 2256-2262

Barnes, D. J., Chalker, B. E. (1990). Calcification and photosynthesis in reef-building corals and algae. In: Dubinsky, Z. (ed.) Coral reefs. Ecosystems of the world, Vol. 25. Elsevier, Amsterdam, p. 109-131

Beardall, J. (1989). Photosynthesis and photorespiration in marine phytoplankton. Aquat. Bot. 34: 105-130

Brakel, W. H. (1979). Small-scale spatial variation in light available to coral reef benthos: quantum irradiance measurements from a Jamaican reef. Bull. mar. Sci. 29: 406-413

Broecker, W. S., Peng, T.-H. (1974). Gas exchange rates between air and sea. Tellus 26: 21-35

Brown, B. E., Le Tissier, M. D. A., Dunne, R. P. (1994). Tissue retraction in the scleractinian coral Coeloseris mayeri, its effect upon coral pigmentation, and preliminary implications for heat balance. Mar. Ecol. Prog. Ser. 105: 209-218

Carpenter, R. C. (1985). Relationships between primary production and irradiance in coral reef algal communities. Limnol. Oceanogr. 30: 784-793

Chalker, B. E. (1981). Simulating light-saturation curves for photosynthesis and calcification by reef-building corals. Mar. Biol. 63: 135-141

Constanz, B. (1986). Coral skeleton construction: a physicochemically dominated process. Palaios 1: 152-157

Crank, J. (1975). The mathematics of diffusion. Clarendon, Oxford

Crossland, C. J., Barnes, D. J. (1977). Gas-exchange studies with the staghorn coral Acropora acuminata and its zooxanthellae. Mar. Biol. 40: 185-194

Dennison, W. C., Bames, D. J. (1988). Effect of water motion on coral photosynthesis and calcification. J. exp. mar. Biol. Ecol, 115: 67-77

Drollet, J. H., Glaziou, P., Martin, P. M. V. (1993). A study of mucus from the solitary coral Fungia fungites (Scleractinia: Fungiidae) in relation to photobiological UV adaptation. Mar. Biol. 115: 263-266 
Edmunds, P. J., Davies, P. S. (1988). Post-illumination stimulation of respiration rate in the coral Porites porites. Coral Reefs 7: 7-9

Falkowski, P. G., Dubinsky, Z., Muscatine, L., Porter, J. W. (1984). Light and bioenergetics of a symbiotic coral. BioSci. 34: 705-709

Falkowski, P. G., Dubinsky, Z., Santostefano, G. (1985). Lightenhanced respiration in phytoplankton. Verh. int. Verein. Limnol. 22: 2830-2833

Falkowski, P. G., Jokiel, P. L., Kinzie, R. A. III (1990). Irradiance and corals. In: Dubinsky, Z. (ed.) Coral reefs. Ecosystems of the world, Vol. 25. Elsevier, Amsterdam, p. 89-107

Garcia, H. E., Gordon, L. I. (1992). Oxygen solubility in seawater: better fitting equations. Limnol. Oceanogr. 37: $1307-1313$

Glud, R. N., Gundersen, J. K., Revsbech, N. P., Jørgensen, B. B. (1994). Effects of the benthic diffusive boundary layer imposed by microelectrodes. Limnol. Oceanogr. 39: 462-467

Glud, R. N., Ramsing, N. B., Revsbech, N. P. (1992). Photosynthesis and photosynthesis-coupled respiration in natural biofilms measured by use of oxygen microsensors. J. Phycol. 28: 51-60

Halldal, P. (1968). Photosynthetic capacities and photosynthetic action spectra of endozoic algae of the massive coral Favia. Biol. Bull. 134: 411-424

Jassby, A. D., Platt, T. (1976). Mathematical formulation of the relationship between photosynthesis and light for phytoplankton. Limnol. Oceanogr. 21: 540-547

Jaubert, J., Vasseur, P. (1974). Light measurements: duration aspect and the distribution of benthic organisms in an Indian Ocean coral reef (Tuléar, Madagascar). Proc. 2nd Int. Coral Reef Symp. 2: 127-142

Jensen, J., Revsbech, N. P. (1989). Photosynthesis and respiration of a diatom biofilm cultured in a new gradient growth chamber. FEMS Microbiol. Ecol. 62: 29-38

Jørgensen, B. B., Cohen, Y., Des Marais, D. J. (1987). Photosynthetic action spectra and adaptation to spectral light distribution in a benthic cyanobacterial mat. Appl. environ. Microbiol. 53: 879-886

Jørgensen, B. B., Des Marais, D. J. (1986). A simple fiber-optic microprobe for high resolution light measurements: application in marine sediment. Limnol. Oceanogr. 31: $1376-1383$

Jørgensen, B. B., Des Marais, D. J. (1988). Optical properties of benthic photosynthetic communities: fiber-optic studies of cyanobacterial mats. Limnol. Oceanogr. 33: 99-113

Jørgensen, B. B., Des Marais, D. J. (1990). The diffusive boundary layer of sediments: oxygen microgradients over a microbial mat. Limnol. Oceanogr. 35: 1343-1355

Jørgensen, B. B., Erez, J., Revsbech, N. P., Cohen, Y. (1985). Symbiotic photosynthesis in a planktonic foraminiferan, Globigerinoides sacculifer (Brady), studied with microelectrodes. Limnol. Oceanogr. 30: 1253-1267

Jørgensen, B. B., Revsbech, N. P. (1985). Diffusive boundary layers and the oxygen uptake of sediments and detritus. Limnol. Oceanogr. 30: 111-122

Kinzie, R. A. III (1993). Effects of ambient levels of solar ultraviolet radiation on zooxanthellae and photosynthesis of the reef coral Montipora verrucosa. Mar. Biol. 116: $319-327$

Kirk, J. T. O. (1983). Light and photosynthesis in aquatic ecosystems. Cambridge University Press, Cambridge

Kühl, M., Jørgensen, B. B. (1992). Spectral light measurements in microbenthic phototrophic communities with a fiber-optic microprobe coupled to a sensitive diode array detector. Limnol. Oceanogr. 37: 1813-1823
Kühl, M., Jørgensen, B, B. (1994). The light field of microbenthic communities: radiance distribution and microscale optics of sandy coastal sediments. Limnol. Oceanogr. 39: 1368-1398

Kühl, M., Lassen, C., Jørgensen, B. B. (1994a). Light penetration and light intensity in sandy marine sediments measured with irradiance and scalar irradiance fiber-optic microprobes. Mar. Ecol. Prog. Ser. 105: 139-148

Kühl, M., Lassen, C., Jørgensen, B. B. (1994b). Optical properties of microbial mats: light measurements with fiberoptic microprobes. In: Stal, L. J., Caumette, P. (eds.) Microbial mats: structure, development and environmental significance. NATO ASI Ser. G, Vol. 35. Springer-Verlag, Berlin, p. 149-167

Lassen, C., Ploug, H., Jørgensen, B. B. (1992). A fibre-optic scalar irradiance microsensor: application for spectral light measurements in sediments. FEMS Microbiol. Ecol. 86: $247-254$

Lesser, M. P., Shick, J. M. (1989). Photoadaptation and defenses against oxygen toxicity in zooxanthellae from natural populations of symbiotic cnidarians. J. exp. mar. Biol. Ecol. 134: 129-141

Li, Y.-H., Gregory, S. (1974). Diffusion of ions in seawater and in deep-sea sediments. Geochim. Cosmochim. Acta 38: $703-714$

Lorenzen, J., Glud, R. N., Revsbech, N. P. (1994). Impact of microsensor-caused changes in diffusive boundary layer thickness on $\mathrm{O}_{2}$ profiles and photosynthetic rates in benthic communities of microorganisms. Mar. Ecol. Prog. Ser. (in press)

Muscatine, L. (1980). Productivity of zooxanthellae. In: Falkowski, P. G. (ed.) Primary productivity in the sea. Plenum Press, New York, p. 381-402

Muscatine, L. (1990). The role of symbiotic algae in carbon and energy flux in reef corals. In: Dubinsky, Z. (ed.) Coral reefs. Ecosystems of the world, Vol. 25. Elsevier, Amsterdam, p. 75-87

Muscatine, L., McCloskey, L. R., Marian, R. E. (1981). Estimating the daily contribution of carbon from zooxanthellae to coral animal respiration. Limnol. Oceanogr. 26: 601-611

Ogren, W. L. (1984). Photorespiration: pathways, regulation and modification. A. Rev. Plant Physiol, 35: 415-442

Patterson, M. R. (1992). A chemical engineering view of cnidarian symbioses. Am. Zool. 32: 566-582

Patterson, M. R., Sebens, K. S., Olson, R. R. (1991). In situ measurements of flow effects on primary production and dark respiration in reef corals. Limnol, Oceanogr. 36: 936-948

Porter, J. W., Muscatine, L., Dubinsky, Z., Falkowski, P. G. (1984). Primary production and photoadaptation in lightand shade-adapted colonies of the symbiotic coral, Stylophora pistillata. Proc. R. Soc. Lond. B 222: 161-180

Prézelin, B. B., Ley, A. C., Haxo, F. T. (1976). Effects of growth irradiance on the photosynthetic action spectra of the marine dinoflagellate, Glenodinium sp. Planta 130: 251-256

Revsbech, N. P. (1989). An oxygen microelectrode with a guard cathode. Limnol. Oceanogr. 34: 474-478

Revsbech, N. P., Jørgensen, B. B. (1983). Photosynthesis of benthic microflora measured with high spatial resolution by the oxygen microprofile method: capabilities and limitations of the method. Limnol. Oceanogr. 28: 749-756

Revsbech, N. P., Jørgensen, B. B. (1986). Microelectrodes: their use in microbial ecology. Adv. microb. Ecol. 9: 293-352

Revsbech, N. P., Jørgensen, B. B., Brix, O. (1981). Primary pro- 
duction of microalgae in sediments measured by oxygen microprofile, $\mathrm{H}^{14} \mathrm{CO}_{3}{ }^{-}$fixation, and oxygen exchange methods. Limnol. Oceanogr. 717-730

Revsbech, N. P., Ward, D. M. (1983). Oxygen microelectrode that is insensitive to medium chemical composition: used in an acid microbial mat dominated by Cyanidium caldarium. Appl. environ. Microbiol. 45: 755-759

Roos, P. J. (1967). Growth and occurrence of the reef coral Porites astreoides Lamarck in relation to submarine radiance distribution. Drukkerij Elinkwijk, Utrecht

Shashar, N., Cohen, Y., Loya, Y. (1993). Extreme fluctuations of oxygen in diffusive boundary layers surrounding stony corals. Biol. Bull. 185: 455-461

Shashar, N., Stambler, N. (1992). Endolithic algae within corals - life in an extreme environment. J, exp. mar. Biol. Ecol. 163: 277-286

Shibata, K. (1969). Pigments and UV-absorbing substance in corals and blue-green alga living in the Great Barrier

This article was submitted to the editor
Reef. Plant Cell Physiol., Tokyo 10: 325-335

Shibata, K., Haxo, F. T. (1969). Light transmission and spectral distribution through epi- and endozoic algal layers in the brain coral, Favia. Biol. Bull. 136: 461-468

Shick, J. M. (1990). Diffusion limitation and hyperoxic enhancement of oxygen consumption in zooxanthellate sea anemones, zoanthids, and corals. Biol. Bull. 179: $148-158$

Trench, R. K. (1981). Cellular and molecular interactions in symbioses between dinoflagellates and marine invertebrates. Pure appl. Chem. 53: 819-835

Vogelmann, T. C., Björn, L. O. 1986. Plants as light traps. Physiol. Plant. 68: 704-708.

Weinberg, S. (1976). Submarine daylight and ecology. Mar. Biol. 37: 291-304

Williams, S. L., Carpenter, R. C. (1990). Photosynthesis / photon flux density relationships among components of coral reef algal turfs. J. Phycol. 26: 40-50

Manuscript first received: July 19, 1994

Revised version accepted: October 27, 1994 